\title{
Systemic Considerations in Child Development and the Pursuit of Racial Equality in the
}

\section{United States}

\author{
Sylvia P. Perry ${ }^{1,2,3}$, Allison L. Skinner-Dorkenoo ${ }^{4}$, James E. Wages III ${ }^{1}$, and Jamie L. Abaied ${ }^{5}$ \\ ${ }^{1}$ Department of Psychology, Northwestern University \\ ${ }^{2}$ Faculty Fellow, Institute for Policy Research, Northwestern University \\ ${ }^{3}$ Department of Medical Social Sciences, Feinberg School of Medicine, Northwestern University \\ ${ }^{4}$ Department of Psychology, University of Georgia \\ ${ }^{5}$ Department of Psychological Science, University of Vermont
}

\begin{abstract}
Author Note
The authors thank Brandon Davis for his help with the preparation of this manuscript, Dr. Larisa Heiphetz for her feedback on the ideas presented here, Drs. Mesmin Destin and Courtney Bonam for their respective feedback on a draft of the manuscript, and Dr. Mahzarin Banaji for introducing the first author to An American Dilemma (Myrdal, 1944).
\end{abstract}

*Correspondence regarding this article can be sent to sylvia.perry@northwestern. 


\title{
CHILD DEVELOPMENT AND THE PURSUIT OF EQUALITY
}

\begin{abstract}
In this commentary on Lewis' (2021) article in Psychological Inquiry, we expand on ways that both systemic and interpersonal contexts contribute to and uphold racial inequalities, with a particular focus on research on child development and socialization. We also discuss the potential roadblocks that may undermine the effectiveness of Lewis' (2021) recommended strategy of relying on experts as a driving force for change. We conclude by proposing additional strategies for pursuing racial equality that may increase the impact of experts, such as starting anti-racist socialization early in development, family-level interventions, and teaching people about racial injustices and their connections to systemic racism.
\end{abstract}

Keywords: racial bias, child development, systemic bias, inequality, prejudice 


\section{CHILD DEVELOPMENT AND THE PURSUIT OF EQUALITY}

Systemic Considerations in Child Development and the Pursuit of Racial Equality in the

United States

Lewis (2021) reflects on the achievement of social equality as the ideal goal within diverse and culturally plural societies, focusing on the U.S., specifically. Lewis argues that, because many people disagree with what equality means and how to pursue it, the goal of equality is difficult to achieve. He concludes by providing recommendations for how the U.S. can move toward equality — namely, by listening to and following the advice of experts on racial inequality. We thank Lewis for his insightful and compelling contribution to Psychological Inquiry. In this commentary on Lewis' work, we briefly expand on ways that both systemic and interpersonal contexts contribute to and uphold racial inequalities, particularly throughout child development. We conclude by discussing additional strategies that go beyond Lewis' suggestion regarding valuing the guidance of experts.

In the late 1930s, the Carnegie Corporation commissioned Gunnar Myrdal, a Swedish economist and sociologist, to conduct an analysis on Black-White relations in the U.S., thinking he would be unbiased, given his national origin. In his over 1,500 page volume, titled $A n$ American Dilemma (1944), Myrdal detailed his travels through the U.S., during which he interviewed hundreds of White and Black people (primarily focusing on the American South), in order to understand the oppression of Black people, which he termed, "The Negro Problem." Myrdal (1944) noted:

When talking about the Negro problem, everybody—not only the intellectual liberals - is thus anxious to locate race prejudice outside of himself. The impersonal "public opinion" or "community feelings" are held responsible. The whites practically never discuss the issue in terms of "I" or "we" but always in 


\section{CHILD DEVELOPMENT AND THE PURSUIT OF EQUALITY}

terms of "they," "people in the South," "people in their community, " or "folks

down here will not stand for..." this or that. We can go around for weeks talking

to white people in all walks of life and consistently hear about the wishes and

beliefs of this collective being, yet seldom meeting a person who actually

identifies himself with it. But he follows it. (p.37)

Myrdal's (1944) work suggested that, despite the systemic issues that contributed to

racial inequality, many White people wanted to avoid acknowledging their role in the oppression of Black people, proclaiming that it was other people's responsibility and that they were not racist. Nearly 80 years later, Myrdal's comments on White Americans' avoidance of race rings painfully true, and a large body of social science research now provides empirical evidence of the continued ways in which White people in the U.S. are encouraged, both subtly and blatantly, to think of race and racism as someone else's problem. Lewis cites much of this work, but primarily focuses on research with adults; we expand upon Lewis' comments, integrating research in developmental and social psychology, and demonstrating that these themes begin developing even in early childhood. As Lewis argues, racial segregation leads to a lack of awareness of racial inequality among White people, as well as a subsequent resistance to the idea that such inequality must be addressed; this lack of awareness affords White people the ability to avoid the harsh realities of racial inequality and maintain positive associations between Whiteness and "goodness" over time. In this commentary, we discuss how the ways that children are socialized to view Whiteness as the default culture also plays a role in sustained racial inequality that broadly impacts people of color in the U.S. 


\section{CHILD DEVELOPMENT AND THE PURSUIT OF EQUALITY}

\section{Racial Biases in Child Development}

From a young age, children in the U.S. are taught both indirectly and directly that the norms and values of White people are favored over the customs of other racial and ethnic groups (Ladson-Billings, 1998; Skinner-Dorkenoo et al., 2021; Sue, 2004). These messages create and maintain a system of racial inequality. For example, by the age of four, White children show explicit and implicit preferences for White over Black children, and these preferences are maintained into adulthood (Dunham et al., 2008; Raabe \& Beelmann, 2011; Skinner \& Meltzoff, 2019). White-favoring norms and values are applied across a variety of areas, including dress codes and hairstyles (Greene, 2013; Opie \& Phillips, 2015), whose linguistic styles are considered "correct" (Baugh, 2000; Craft et al., 2020; Lindemann, 2005; Williams, 1997), what music and art are valued (with a focus on contributions by White artists; Acuff, 2018; Bradley, 2007; Roy \& Dowd, 2010), the languages and cultures that children learn about in school (e.g., a focus on Western civilization; Semple 2014), and how intellectual abilities are assessed (e.g., contextualization of questions on standardized tests; Boykin, 1977; Johnston, 2010; Sue, 2017). These values even extend to the spaces that we occupy, with people associating more positivity and worth with predominantly White spaces (Bonam et al., 2016; Bonam et al., 2017; Bonam et al., 2020). The aforementioned practices center White people and culture as the norm (or default) and frame all others as deviant (Skinner-Dorkenoo et al., 2021), resulting in strong racial indoctrination in the education system that starts in early childhood (Acuff, 2018; Miller \& Harris, 2018; Solorzano, 1997). The establishment of strong positive associations with White culture and norms is worthy of attention because both adults and children have a tendency to accept the status quo as legitimate (e.g., Kay et al., 2009; Roberts et al., 2016). Moreover, early on, children learn to value those who have been advantaged in society-whether it be via wealth 


\section{CHILD DEVELOPMENT AND THE PURSUIT OF EQUALITY}

or success (e.g., Olson et al., 2006; Li et al., 2014; Shutts et al., 2016). All of these factors triangulate upon the same message-White people and their associated cultural values represent the ideal that one should strive for. Meanwhile, few White parents of White children actively push for the values and norms of people of color to be equally represented, in spite of their stated endorsement of egalitarianism (Dovidio \& Gaertner, 2000, Hagerman, 2017; Hagerman, 2020). The growing literature on racial socialization in White families helps to contextualize this pattern.

Recent work on racial and ethnic socialization in White U.S. families shows a consistent pattern of White parents of White children avoiding discussions of race or racism with their children, often citing a need to shield their child from the realities of racism, or taking a passive approach (e.g., waiting for their child to bring it up; Abaeid \& Perry, 2021; Abaied et al., 2021). Among White parents who do discuss race with their children, some show a personal recognition of their own prejudices and explicitly discuss racism with their children (Perry et al., 2019; Abaied et al., 2021; Abaeid \& Perry, 2021), but most fail to directly tackle the issue of systemic racism and the origins of racial inequality, and instead tend to emphasize colorblindness (e.g., stating that race does not matter) or downplay the significance of racism (Abaied \& Perry, 2021; Abaied et al., 2021; Vittrup, 2018; Zucker \& Patterson, 2018). Colorblind ideologies not only obscure the reality of racism, but may also give rise to and perpetuate a system of inequality. We know that children who receive colorblind messages about race are less able to recognize and identify racial discrimination (Apfelbaum et al., 2010). Furthermore, because children do not receive obvious cues or information to explain racial disparities through parental socialization or education, they must make their own attributions for why certain social groups are treated more positively than others. This often means attributing racial disparities to internal qualities of racial 


\section{CHILD DEVELOPMENT AND THE PURSUIT OF EQUALITY}

groups (e.g., competence or morality) rather than the external qualities that actually give rise to the disparities (e.g., systemic biases; Brey \& Pauker, 2019; Hetey \& Eberhardt, 2018; Olson et al., 2011; Roberts \& Rizzo, 2021; Vittrup, 2018)

At a societal level, colorblind positions and policies allow systemic racial discrimination (e.g., all White juries for Black defendants; Alexander, 2020; Raphael \& Ungvarsky, 1993; Sommers \& Norton, 2007) and racially biased policies (e.g., racially disparate exposure to environmental toxins; Washington, 2019) to persist, so long as they are justified with raceneutral explanations. Colorblind thinking also perpetuates the myth that the U.S. is a meritocracy, another societal ideology that is indoctrinated from an early age (Batruch et al., 2019; Betz \& Kayser, 2017; Butera et al., 2021). By getting the U.S. public to buy into the myth of meritocracy, those with the power can distribute the work of upholding the system that benefits them by convincing others that they could have a slice of the pie too, if they just work hard enough. This framework also provides a default explanation for anyone who does not succeed in the system - they simply did not work as hard as other, more successful people did, and perhaps most importantly, systemic racism is completely absent as an explanation for failure (van Dijk et al., 2020; Liu, 2011). Beyond the consequences for child development, promoting colorblindness as a personal ideology and as a systemic policy in education, law, and other systems, has served to uphold White supremacy, but also made it much harder to detect and prosecute (Bonilla-Silva, 2002; Mueller, 2017; Salter et al., 2018).

Colorblind ideologies not only deny the reality of racism, but they also deny the contributions of people of color to American society. The contributions and accomplishments of people of color are omitted from educational curricula or confined to a particular week or month. Designating only one month a year for the teaching of Black history, for example, and largely 


\section{CHILD DEVELOPMENT AND THE PURSUIT OF EQUALITY}

omitting the histories of other racial and ethnic groups altogether is a widespread example of this practice. Teaching history in this way supports the notion that people of color and their experiences are not essential, mainstream knowledge that should be integrated into the educational landscape. Furthermore, the stories of people of color are typically framed in terms of their relations with White people, which suggests that these groups do not have their own, unique histories at all, outside of their interactions with White people and White culture (e.g., the experiences of Native Americans; Fryberg \& Eason, 2017).

Beyond the limited coverage of contributions of people of color, mainstream educational curricula in the U.S. often downplays the horrific abuses of the past—such as Native American genocide and violent attacks on civil rights leaders - while avoiding acknowledgment of the systemic nature of past racial atrocities such as colonization and slavery (Brown \& Brown, 2010; Eason et al., 2021; Salter \& Adams, 2016). Denying the systemic nature of racism within educational contexts perpetuates a narrative that racism can be explained by a few bad apples (e.g., specific, barbaric slaveholders; the Ku Klux Klan) and fails to correctly frame these atrocities as indicative of systemic racism (Brown \& Brown, 2010). These educational methods further reinforce the notion of White goodness; for example, children are taught to view Christopher Columbus as the bringer of "civilization" to the Native Americans and learn about isolated incidents of "nice" slave-holders (Brown \& Brown, 2010; Eason et al., 2021; Fryberg \& Eason, 2017; Shammas, 2021). Similar messages are also communicated through artifacts, such as school namesakes. A recent investigation indicated that although fewer than $10 \%$ of Chicago Public School students are White, $72 \%$ of public school namesakes were White- 30 of whom were known to be slaveholders (FitzPatrick, 2020). Dozens of U.S. colleges and universities were built by enslaved people, yet for many institutions these contributions remain 


\section{CHILD DEVELOPMENT AND THE PURSUIT OF EQUALITY}

unacknowledged, and very few have explicitly addressed the consequences of this legacy of slavery (Thomson, 2019). In fact, in many cases, buildings, statues, and structures named in honor of slave-holders and supporters of the Confederacy remain (Smith \& Ellis, 2017). For students who are socialized in these contexts, where the status differences between racial groups are normalized and justified, systemic inequalities can be passively absorbed without criticism (Payne et al., 2019; Vuletich \& Payne, 2019). As a result, racial hierarchies do not seem problematic; they merely appear to be the natural order of things.

\section{Pursuing Racial Equality}

Despite the expertise Myrdal provided in his reporting of White people's reluctance to personally take responsibility for racism and actively support policies to mitigate racism in the U.S. (Myrdal, 1944), far too little racial progress has been made. This is made clear by overwhelming evidence of psychological and systemic racial biases - as well as the disparate consequences of such biases - that persist to this day. It seems that the expertise of Myrdal and other noteworthy historical researchers of prejudice and intergroup conflict (e.g., Allport et al., 1954; Clark \& Clark, 1950; LaPiere, 1934; Sherif et al., 1961) have not sufficiently changed White people's willingness to address racial inequality as a personal and urgent matter. The lack of racial progress, despite this early and popular work on prejudice, suggests that the appeal of experts on racism might prove ineffective at convincing the American public of the value of fully pursuing racial equity. America has a long history of anti-intellectualism or aversion of experts (Hofstader, 1963), which has been trending upward since 2015 amid the anti-intellectual rhetoric propelled by recent politics in the U.S. (Motta, 2018). There is also declining support of American institutions of higher education in the U.S., due to anti-liberal attitudes toward college faculty (Parker, 2019), the vast source of expertise on racism. Given the continued rise of anti- 


\section{CHILD DEVELOPMENT AND THE PURSUIT OF EQUALITY}

intellectualism and current affective polarization in the U.S. (Iyengar et al., 2019), spotlighting the influence of experts on racism or providing them with policy decision-making power could not only potentially be ineffective, but even motivate counterproductive backlash. Of course, following the research and advice from experts is critical to successfully pursuing equality; however, efforts to pursue equality under the advice of experts need to be practically considered to avoid anti-intellectual defensiveness. So how can we effectively apply expertise to dismantling racial inequality, in the context of these constraints?

The literature reviewed above suggests that people in the U.S. - and children in particular - should be exposed to more information about systemic racism and how cultural norms uphold and perpetuate systemic inequality. From a developmental perspective, it would be particularly advantageous to begin this socialization process early in development before children's racial attitudes and stereotypes are formed and crystallized. Children show explicit group-based biases as early as 3-years-old (Skinner \& Meltzoff, 2019), and behavioral evidence suggestive of group-based biases (e.g., looking time measures) has been observed within the first few months of life (Bar-Haim et al., 2006; Kinzler \& Spelke, 2011; Quinn et al., 2018; Quinn et al., 2016). Pro-White bias emerges among White Americans as early as age four (Perszyk et al., 2019), and reluctance to openly speak about race intensifies from early to mid-childhood (Pauker et al., 2015), suggesting that early childhood represents a potentially critical developmental window for racial socialization. Intervening early is particularly crucial because, by middlechildhood, the majority of children of color report having experienced racial discrimination (with the majority of these acts being perpetuated by White children; Pachter et al., 2010), and these experiences continue to increase into adolescence and are associated with poor health outcomes for Black children (Seaton \& Douglass, 2014). 


\section{CHILD DEVELOPMENT AND THE PURSUIT OF EQUALITY}

Developmental and social psychological research suggests that being taught about or reflecting on the history of racism in the U.S. can potentially reduce inequality through increasing intergroup empathy and knowledge and concern about systemic racism. For example, Hughes et al. (2007) show that when White children are taught about the history of racism, they are more likely to value racial fairness, endorse counterstereotypic beliefs, and show positive attitudes and empathy toward Black people. Additionally, Nelson et al. (2013) and Bonam et al. (2019) show that these processes work similarly in adults—when White adults know more about the history of racism, they are more likely to recognize that racism can be systemic (e.g., identifying that the practice of racial profiling or higher rates of poverty among people of color in the U.S. is due to racism). Specifically, White people who learned about the history of racial discrimination in U.S. housing policies were better able to identify present-day instances of systemic racism than those who did not learn about this history (Bonam et al., 2019). What these interventions have in common is that they seek to correct misinformation about racism, as well as fill in the gaps in White individuals' knowledge of racism that arise due to the systemic issues reviewed above. These interventions also have the advantage of leveraging the knowledge base developed by experts—as Lewis suggested — in ways that focus on individuals, providing a complementary approach to efforts to reduce racial inequality at the policy level.

Despite these promising avenues for prevention and intervention, it is important to acknowledge that there are many potential challenges to this approach, given that even wellmeaning — so-called "woke" — White people often avoid discussing race and racism, including with their children (Abaied \& Perry, 2021; Apfelbaum et al., 2012; Hagerman, 2017; Underill, 2018; Vittrup, 2018; Zucker \& Patterson, 2018). In fact, our recent work showed that, even after the 2020 Black Lives Matter movement and the death of George Floyd, one-third of White 


\section{CHILD DEVELOPMENT AND THE PURSUIT OF EQUALITY}

parents downplayed or even refuted the reality of U.S. racism in discussions with their White adolescent children (Abaied et al., 2021). Moreover, many White families who identify as progressive actively choose to enroll their children in schools and live in neighborhoods that are overwhelmingly White—despite stating they value racial integration and diversity—but justify their segregating preferences with colorblind explanations (Chang, 2018). The lack of interracial contact, however, may facilitate the development of children's intergroup prejudice. Hagerman (2020) discusses this paradox in her book White Kids: Growing Up with Privilege in a Racially Divided America, noting:

But neighborhoods are also foundational to the concept of a racial context of childhood...When parents make decisions about where to live, often they are simultaneously and strategically making decisions about schools. In turn, decisions about schools shape a range of other parenting decisions such as what extracurricular activities to participate in, which Little League team to join, what carpool makes the most sense, who the babysitters will be, and so forth. In this sense, parents are not only deciding where to live when they select a neighborhood but also making a larger set of decisions about the parameters of their child's life — parameters include a host of external forces that shape how kids form ideas about race, racism, inequality, and privilege. (pp. 57-58)

Empirical research corroborates Hagerman's (2020) observations. For example, the racial diversity of parents' friendships predicts White children's racial prejudices in early childhood, such that White children whose parents (i.e., both mothers and fathers) have more cross-race (i.e., non-White) friendships, have more positive attitudes toward people of color (Pahlke et al., 2012; Vittrup \& Holden, 2011). Moreover, the racial diversity of children's environments can 


\section{CHILD DEVELOPMENT AND THE PURSUIT OF EQUALITY}

shape prejudice development from infancy. Although infants raised in racially homogeneous environments show a preference for same race faces as early as 3-months, those who are raised in racially mixed environments do not show such patterns (Bah-Haim et al., 2006). Likewise, White babies (7 to 12-month-olds) who live in more (compared to less) racially diverse neighborhoods show neural responses indicative of greater attention to the faces of people of color (Hwang et al., 2020). All of this suggests that the early environments that parents cultivate for their children seem to set the stage for their racial attitudes, such that choosing predominantly White neighborhoods and schools has measurable consequences.

Regardless of where White families live, one step parents can take to begin challenging these structural influences is to improve the frequency and content of family conversations about race. Our research group recently developed a guided discussion task in which parents and children watch a series of animated vignettes depicting White children displaying subtle or more blatant forms of racism toward Black children (e.g., feeling uncomfortable around Black children; intentionally kicking a ball at a child because they are Black). After each vignette, White parent-child dyads responded to a series of prompts designed to facilitate color-conscious conversations about racism. Preliminary results suggest the method facilitated color-conscious conversations, such that parents mentioned race and pointed out that prejudice had occurred in the vignettes at a higher rate than previous self-report and lab studies have shown. Furthermore, both parents and children showed decreased pro-White/anti-Black implicit attitudes after the conversation (Perry et al., 2021). Despite the aforementioned barriers, we believe that interventions at the family level have the potential to be high impact, as two generations can be targeted at once, and families can potentially encourage children to be critical of the colorblind, White-centric messages they receive at school or in other contexts. 


\section{CHILD DEVELOPMENT AND THE PURSUIT OF EQUALITY}

\section{Conclusion}

Myrdal concluded An American Dilemma by explaining that, despite the fact that White Americans thought that racism and racial inequality would just fade away over time, they needed to take a more active approach to create this ideal system of equality - the American dream. Specifically, Myrdal (1944) noted:

It was believed by most well-meaning people that self-healing would come to solve itself by the lapse of time... This nation early laid down as the moral basis for its existence the principles of equality and liberty. ...yet although they are one-tenth of the population, Blacks are treated as inferior... and denied civil rights...In this sense the Negro problem is not only America's greatest failure but also America's incomparable great opportunity for the future. (pp.1021-1022)

Ultimately, the expert (Myrdal) concluded that the problem was White people and how they think about and structure society. Despite the immense popularity of his book among the American public and the fact that it did motivate some policy change (Brown v. Board of Education, Warren \& Supreme Court of The United States, 1953), many of the same issues persist to this day. As such, we argue that, although relying on experts may be an appealing recommendation, history suggests that our efforts to reduce racial inequality in the U.S. will require substantial, widespread investment from White U.S. residents in order for real change to occur. Based on the literature reviewed here, significant barriers to such investment remain, many of which begin in early childhood. Beyond pursuing policies that promote structural equality on the advice of experts in ways that do not trigger backlash, we should support policies that educate the public — with a special emphasis on childhood socialization — on the history of 


\section{CHILD DEVELOPMENT AND THE PURSUIT OF EQUALITY}

systemic racism and the past and continued intentional efforts to create and maintain racial inequalities.

Building upon recommendations offered by Lewis, we also argue that we need to move the societal bar from simply being non-racist, to being actively anti-racist. As a society, we need to recalibrate our norms, such that passively going along with systemic racism will no longer be acceptable (Tatum, 2017). In the summer of 2020, after the police killings of George Floyd and Breonna Taylor, many organizations released statements in support of the Black Lives Movement, confronting systemic racism, and increasing social justice (Nguyen, 2020). But one question that many posed was whether these organizations and institutions were genuinely committed to tackling systemic racism, or if their acts were performative (Duarte, 2020). If groups, organizations, and institutions want to claim that they are committed to anti-racism, then they should be held accountable for these claims and provide concrete evidence of their efforts to dismantle the pervasive system of racial oppression. In addition to this, we recommend a greater investment in educating the public on the history of systemic racism (particularly with children; such as the Ethnic Studies Model Curriculum implemented in the state of California), prompting White parents to actively be anti-racist and teach their children to do the same, and equitable structural policies that facilitate residential and school racial integration to increase quality interracial contact. 


\section{CHILD DEVELOPMENT AND THE PURSUIT OF EQUALITY}

\section{References}

Abaied, J. L., Perry, S. P. (2021). Socialization of racial ideology by White parents. Cultural Diversity \& Ethnic Minority Psychology.

Abaied, J. L., Perry, S., Cheaito, A., \& Ramirez, V. (2021, April 15). Talking more and saying less: White parents' discussions of race-related current events before and after the 2020 Black Lives Matter protests. https://doi.org/10.31234/osf.io/w6qzn

Acuff, J. B. (2018). Smog in the air: Passive positions, deracialization, and erasure in arts education. In A. Kraehe, R. Gaztambide-Fernández, B. Carpenter II (Eds.) The Palgrave handbook of race and the arts in education (pp. 515-533). Palgrave Macmillan, Cham. https://doi.org/10.1007/978-3-319-65256-6_30

Alexander, M. (2020). The new Jim Crow: Mass incarceration in the age of colorblindness. The New Press.

Allport, G. W., Clark, K., \& Pettigrew, T. (1954). The Nature of Prejudice.

Apfelbaum, E. P., Norton, M. I., \& Sommers, S. R. (2012). Racial color blindness: Emergence, practice, and implications. Current Directions in Psychological Science, 21(3), 205-209.

Apfelbaum E.P., Pauker K., Sommers S.R., Ambady N. (2010) In Blind Pursuit of Racial Equality? Psychological Science;21(11):1587-1592. doi:10.1177/0956797610384741

Bar-Haim, Y., Ziv, T., Lamy, D., \& Hodes, R. M. (2006). Nature and nurture in own-race face processing. Psychological Science, 17(2), 159-163. https://doi.org/10.1111/j.14679280.2006.01679.x

Batruch A., Autin F., Butera F. (2019) The Paradoxical Role of Meritocratic Selection in the Perpetuation of Social Inequalities at School. In: Jetten J., Peters K. (eds) The Social Psychology of Inequality. Springer, Cham. https://doi.org/10.1007/978-3-030-28856-3_8 


\section{CHILD DEVELOPMENT AND THE PURSUIT OF EQUALITY}

Baugh, J. (2000). Beyond Ebonics: Linguistic pride and racial prejudice. Oxford University Press on Demand.

Betz, T., \& Kayser, L. B. (2017). Children and society: Children's knowledge about inequalities, meritocracy, and the interdependency of academic achievement, poverty, and wealth. American Behavioral Scientist, 61(2), 186-203.

Bonam, C. M., Bergsieker, H. B., \& Eberhardt, J. L. (2016). Polluting Black space. Journal of Experimental Psychology: General, 145(11), 1561-1582.

Bonam, C. M., Nair Das, V., Coleman, B. R., \& Salter, P. (2019). Ignoring history, denying racism: Mounting evidence for the Marley hypothesis and epistemologies of ignorance. Social Psychological and Personality Science, 10(2), 257-265.

Bonam, C. M., Taylor, V. J., \& Yantis, C. (2017). Racialized physical space as cultural product. Social and Personality Psychology Compass, 11(9), e12340.

Bonam, C., Yantis, C., \& Taylor, V. J. (2020). Invisible middle-class Black space: Asymmetrical person and space stereotyping at the race-class nexus. Group Processes \& Intergroup Relations, 23(1), 24-47.

Bonilla-Silva, E. (2002). The Linguistics of Color Blind Racism: How to Talk Nasty About Blacks Without Sounding "Racist”. Critical Sociology. 28. 41-64. $10.1177 / 08969205020280010501$.

Boykin, A. W. (1977). Experimental psychology from a black perspective: Issues and examples. Journal of Black Psychology, 3(2), 29-49. https://doi.org/10.1177/009579847700300209

Bradley, D. (2007). The sounds of silence: Talking race in music education. Action, Criticism, and Theory for Music Education, 6(4), 132-162. 


\section{CHILD DEVELOPMENT AND THE PURSUIT OF EQUALITY}

Brey, E., \& Pauker, K. (2019) Teachers' nonverbal behaviors influence children's stereotypic beliefs, Journal of Experimental Child Psychology, 188, 104671. https://doi.org/10.1016/j.jecp.2019.104671.

Brown, K. D., \& Brown, A. L. (2010). Silenced memories: An examination of the sociocultural knowledge on race and racial violence in official school curriculum. Equity \& Excellence in Education, 43(2), 139-154.

Butera, F., Batruch, A., Autin, F., Mugny, G., Quiamzade, A., \& Pulfrey, C. (2021). Teaching as social influence: Empowering teachers to become agents of social change. Social Issues and Policy Review, 15(1), 323-355.

Chang, A. (2018, July 31). White America is quietly self-segregating. Vox. https://www.vox.com/2017/1/18/14296126/white-segregated-suburb-neighborhoodcartoon

Clark, K. B., \& Clark, M. P. (1950). Emotional factors in racial identification and preference in Negro children. Journal of Negro Education, 19(3), 341-350.

Craft, J. T., Wright, K. E., Weissler, R. E., \& Queen, R. (2020). Language and discrimination: Generating meaning, perceiving identities, and discriminating outcomes. Annual Review of Linguistics, 6(1), 389-407. https://doi.org/10.1146/annurev-linguistics-011718-011659

Dovidio, J. F., \& Gaertner, S. L. (2000). Aversive racism and selection decisions: 1989 and 1999.Psychological Science,11(4), 315-319.

Duarte, F. (2020, June 12). Big brands have spoken out in support of black communities following George Floyd's killing. How as a consumer do you know which companies genuinely support the cause? BBC. https://www.bbc.com/worklife/article/20200612black-lives-matter-do-companies-really-support-the-cause 


\section{CHILD DEVELOPMENT AND THE PURSUIT OF EQUALITY}

Dunham, Y., Baron, A. S., \& Banaji, M. R. (2008). The development of implicit intergroup cognition. Trends in Cognitive Sciences, 12(7), 248-253.

Eason, A. E., Pope, T., Becenti, K. M., \& Fryberg, S. A. (2021). Sanitizing History: National Identification, Negative Stereotypes, and Support for Eliminating Columbus Day and Adopting Indigenous Peoples Day. Cultural Diversity and Ethnic Minority Psychology, 27(1), 1-17. https://doi.org/10.1037/cdp0000345

FitzPatrick, L. "30 Public Schools in Chicago Are Named for Slaveholders; Surprised CPS Promises Changes.” Times, Chicago Sun-Times, 30 Dec. 2020, chicago.suntimes.com/2020/12/30/22189499/cps-school-names-slaveholders-chicagopublic-schools-maurice-swinney-john-marshall-agassiz-acero.

Fryberg, S. A., \& Eason, A. E. (2017). Making the invisible visible: Acts of commission and omission. Current Directions in Psychological Science, 26(6), 554-559.

Greene, D. W. (2013). A multidimensional analysis of what not to wear in the workplace: Hijabs and natural hair. Florida International University Law Review, 8, 333-362. https://doi.org/10.25148/lawrev.8.2.8

Hagerman, M. A. (2017). White racial socialization: Progressive fathers on raising "antiracist" children. Journal of Marriage and Family, 79(1), 60-74.

Hagerman, M. A. (2020). White kids: Growing up with privilege in a racially divided America (Vol. 1). NYU Press.

Hetey, R. C., \& Eberhardt, J. L. (2018). The numbers don't speak for themselves: Racial disparities and the persistence of inequality in the criminal justice system. Current Directions in Psychological Science, 27(3), 183-187

Hofstadter, R. (1963). Anti-intellectualism in American Life.(3. Print.) (Vol. 713). Vintage. 


\section{CHILD DEVELOPMENT AND THE PURSUIT OF EQUALITY}

Hughes, J. M., Bigler, R., \& Levy, S. (2007). Consequences of learning about historical racism among European and African American children. Child Development, 78, 1689-1705.

Hwang, H. G., Debnath, R., Meyer, M., Salo, V. C., Fox, N. A., \& Woodward, A. (2020). Neighborhood racial demographics predict infants' neural responses to people of different races. Developmental Science, e13070.

Iyengar, S., Lelkes, Y., Levendusky, M., Malhotra, N., \& Westwood, S. J. (2019). The origins and consequences of affective polarization in the United States. Annual Review of Political Science, 22, 129-146.

Johnston, P. M. G. (2010). Towards culturally appropriate assessment? A contribution to the debates. Higher Education Quarterly, 64(3), 231-245. https://doi.org/10.1111/j.14682273.2010.00463.x

Kay, A. C., Gaucher, D., Peach, J. M., Laurin, K., Friesen, J., Zanna, M. P., \& Spencer, S. J. (2009). Inequality, Discrimination, and the Power of the Status Quo: Direct Evidence for a Motivation to See the Way Things Are as the Way They Should Be. Journal of Personality and Social Psychology, 97(3), 421-434. https://doi.org/10.1037/a0015997

Kinzler, K. D., \& Spelke, E. S. (2011). Do infants show social preferences for people differing in race? Cognition, 119(1), 1-9.

Ladson-Billings, G., (1998) Just what is critical race theory and what's it doing in a nice field like education?, International Journal of Qualitative Studies in Education, 11:1, 7-24, DOI: $10.1080 / 095183998236863$

LaPiere, R. T. (1934). Attitudes vs. actions. Social Forces, 13(2), 230-237. 


\section{CHILD DEVELOPMENT AND THE PURSUIT OF EQUALITY}

Li, V., Spitzer, B., \& Olson, K. R. (2014). Preschoolers reduce inequality while favoring individuals with more. Child Development, 85(3), 1123-1133.

Lindemann, S. (2005). Who speaks “broken English”? US undergraduates’ perceptions of nonnative English. International Journal of Applied Linguistics, 15(2), 188-212. https://doi.org/10.1111/j.1473-4192.2005.00087.x

Liu, A. (2011). Unraveling the myth of meritocracy within the context of US higher education. Higher Education, 62(4), 383-397.

Miller, L. A., \& Harris, V. W. (2018). I Can't Be Racist-I Teach in an Urban School, and I'm a Nice White Lady! World Journal of Education, 8(3), 1.

https://doi.org/10.5430/wje.v8n3p1

Motta, M. (2018). The dynamics and political implications of anti-intellectualism in the United States. American Politics Research, 46(3), 465-498.

Mueller, J. C. (2017). Producing colorblindness: Everyday mechanisms of White ignorance. Social Problems, 64, 219-238. doi:10.1093/socpro/spw061

Myrdal, G., et al. (1944). An American dilemma; the Negro problem and modern democracy. (2 Vols.). Harper.

Nelson, J. C., Adams, G., \& Salter, P. S. (2013). The Marley hypothesis: Denial of racism reflects ignorance of history. Psychological Science, 24(2), 213-218.

Nguyen, T. (2020, June 3). Consumers don't care about corporate solidarity. They want donations. Vox. https://www.vox.com/the-goods/2020/6/3/21279292/blackouttuesdaybrands-solidarity-donations

Olson, K.R., Banaji, M. R., Dweck, C. S., \& Spelke, E. S. (2006). Children’s bias against lucky vs. unlucky people and their social groups. Psychological Science, 17, 845-846. 


\section{CHILD DEVELOPMENT AND THE PURSUIT OF EQUALITY}

Olson, K. R., Dweck, C. S., Spelke, E. S., \& Banaji, M. R. (2011). Children’s responses to group-based inequalities: Perpetuation and rectification. Social Cognition, 29, 271-288.

Opie, T. R., \& Phillips, K. W. (2015). Hair penalties: The negative influence of Afrocentric hair on ratings of Black women's dominance and professionalism. Frontiers in Psychology, 6, 1311. https://doi.org/10.3389/fpsyg.2015.01311

Pachter, L. M., Bernstein, B. A., Szalacha, L. A., \& Coll, C. G. (2010). Perceived racism and discrimination in children and youths: An exploratory study. Health \& Social Work, 35(1), 61-69.

Parker, K. (2019, January 30) "Views of Higher Education Divided by Party.” Pew Research Center's Social \& Demographic Trends Project, Pew Research Center, www.pewresearch.org/social-trends/2019/08/19/the-growing-partisan-divide-in-views-ofhigher-education-2/.

Pahlke, E., Bigler, R. S., \& Suizzo, M.-A. (2012). Relations between colorblind socialization and children's racial bias: evidence from European American mothers and their preschool children. Child Development, 83(4), 1164-79. doi: 10.1111/j.1467-8624.2012.01770.x

Pauker, K., Apfelbaum, E. P., \& Spitzer, B. (2015). When societal norms and social identity collide: The race talk dilemma for racial minority children. Social Psychological and Personality Science, 6, 887-895. https://doi.org/10.1177/1948550615598379

Payne, B. K., Vuletich, H. A., \& Brown-Iannuzzi, J. L. (2019). Historical roots of implicit bias in slavery. Proceedings of the National Academy of Sciences, 116(24), 11693-11698.

Perry, S. P., Skinner, A. L., \& Abaied, J. L. (2019). Bias awareness predicts color conscious racial socialization methods among White parents. Journal of Social Issues, 75(4), 10351056. 


\section{CHILD DEVELOPMENT AND THE PURSUIT OF EQUALITY}

Perry, S., Skinner-Dorkenoo, A., Abaied, J. L., Osnaya, A., \& Waters, S. (2021, March 15). Initial Evidence that Parent-Child Conversations About Race Reduce Racial Biases Among White U.S. Children. https://doi.org/10.31234/osf.io/3xdg8

Perszyk, D. R., Lei, R. F., Bodenhausen, G. V., Richeson, J. A., \& Waxman, S. R. (2019). Bias at the intersection of race and gender: Evidence from preschool-aged children. Developmental Science, 22(3), e12788.

Quinn, P. C., Lee, K., \& Pascalis, O. (2018). Face Processing in Infancy and Beyond: The Case of Social Categories. Annual Review of Psychology, (June), 1-25.

Quinn, P. C., Lee, K., Pascalis, O., \& Tanaka, J. W. (2016). Narrowing in categorical responding to other-race face classes by infants. Developmental Science, 19(3), 362-371. https://doi.org/10.1111/desc.12301

Raabe T, Beelmann A. (2011). Development of ethnic, racial, and national prejudice in childhood and adolescence: a multinational meta-analysis of age differences. Child Development, 82(6):1715-37. doi: 10.1111/j.1467-8624.2011.01668.x. Epub 2011 Oct 24. PMID: 22023224.

Raphael, M. J., \& Ungvarsky, E. J. (1993). Excuses, excuses: Neutral explanations under Batson v. Kentucky. University of Michigan Journal of Law Reform, 27(1), 229-275.

Roberts, S.O., Gelman, S.A. and Ho, A.K. (2016). So it is, so it shall be: Group regularities license children's prescriptive judgments. Cognitive Science, 41: 576-600.

https://doi.org/10.1111/cogs.12443

Roberts, S. O., \& Rizzo, M. T. (2021). The psychology of American racism. American Psychologist, 76(3), 475-487. https://doi.org/10.1037/amp0000642 


\section{CHILD DEVELOPMENT AND THE PURSUIT OF EQUALITY}

Roy, W. G., \& Dowd, T. J. (2010). What is sociological about music? Annual Review of Sociology, 36, 183-203. https://doi.org/10.1146/annurev.soc.012809.102618

Salter, P. S., \& Adams, G. (2016). On the intentionality of cultural products: Representations of Black history as psychological affordances. Frontiers in Psychology, 1-21. https://doi.org/10.3389/fpsyg.2016.01166

Salter PS, Adams G, Perez MJ (2018). Racism in the Structure of Everyday Worlds: A Cultural-Psychological Perspective. Current Directions in Psychological Science. 27(3):150-155. doi:10.1177/0963721417724239

Seaton, E. K., \& Douglass, S. (2014). School diversity and racial discrimination among AfricanAmerican adolescents. Cultural Diversity and Ethnic Minority Psychology, 20(2), 156165.

Semple, K. (2014, January 30). “A Big Advocate of French in New York's Schools: France.” The New York Times,www.nytimes.com/2014/01/31/nyregion/a-push-for-french-in-new-yorkschools-from-france.html.

Shammas, B. (2021, March 15). Students were told to 'tweet' from the Civil War era. The school showcased their proslavery posts. The Washington Post. https://www.washingtonpost.com/education/2021/03/14/civil-war-tweet-assignment/.

Shutts, K., Brey, E. L., Dornbusch, L. A., Slywotzky, N., \& Olson, K. R. (2016). Children use wealth cues to evaluate others. PloS one, 11(3), e0149360.

Skinner, A. L., \& Meltzoff, A. N. (2019). Childhood experiences and intergroup biases among children. Social Issues and Policy Review, 13(1), 211-240.

https://doi.org/10.1111/sipr.12054 


\section{CHILD DEVELOPMENT AND THE PURSUIT OF EQUALITY}

Skinner-Dorkenoo, A., Sarmal, A., Andre, C., \& Rogbeer, K. (2021). How Microaggressions Reinforce and Perpetuate Systemic Racism in the U.S.. Perspectives on Psychological Science.

Smith, S., and Ellis, E. (2020) "History Shows Slavery Helped Build Many U.S. Colleges and Universities." Shackled Legacy | APM Reports, www.apmreports.org/episode/2017/09/04/shackled-legacy.

Solorzano, D. (1997). Images and Words that Wound. Teacher Education Quarterly, 24(3), 519. $\quad$ https://doi.org/10.1016/S0969-4765(04)00066-9

Sommers, S. R., \& Norton, M. I. (2007). Race-based judgments, race-neutral justifications: experimental examination of peremptory use and the Batson challenge procedure. Law and Human Behavior, 31(3), 261-273. https://doi.org/10.1007/s10979-006-9048-6

Sue, D. W. (2004). Whiteness and ethnocentric monoculturalism: Making the " invisible" visible. American Psychologist, 59(8), 761-769. https://doi.org/10.1037/0003066X.59.8.761

Sue, D. W. (2017). Microaggressions and "evidence”: Empirical or experiential reality? Perspectives on Psychological Science, 12(1), 170-172. https://doi.org/10.1177/1745691616664437

Tatum, B. D. (2017). Why are all the black kids sitting together in the cafeteria?: and other conversations about race. Basic Books.

Thompson, C. (2019) How a growing number of US colleges are paying 'reparations' to descendants of slavery victims. The Independent. https://www.independent.co.uk/news/world/americas/us-politics/universities-reparationsslavery-georgetown-virginia-princeton-a9247091.html. 


\section{CHILD DEVELOPMENT AND THE PURSUIT OF EQUALITY}

Underhill, M. R. (2018). Parenting during Ferguson: making sense of white parents' silence. Ethnic and Racial Studies, 41(11), 1934-1951. doi:10.1080/01419870.2017.1375132

University of Oklahoma. Institute of Group Relations, \& Sherif, M. (1961). Intergroup conflict and cooperation: The Robbers Cave experiment (Vol. 10, pp. 150-198). Norman, OK: University Book Exchange.

van Dijk, H., Kooij, D., Karanika-Murray, M., De Vos, A., \& Meyer, B. (2020). Meritocracy a myth? A multilevel perspective of how social inequality accumulates through work. Organizational Psychology Review, 10(3-4), 240-269.

Vittrup, B. (2018). Color blind or color conscious? White American mothers' approaches to racial socialization. Journal of Family Issues, 39, 668-692. https://doi.org/10.1177/0192513X16676858

Vittrup, B., \& Holden, G. W. (2011). Exploring the impact of educational television and parentchild discussions on children's racial attitudes. Analyses of Social Issues and Public Policy, 11(1), 82-104.

Vuletich, H. A., \& Payne, B. K. (2019). Stability and change in implicit bias. Psychological Science, 30(6), 854-862.

Warren, E. \& Supreme Court of The United States. (1953) U.S. Reports: Brown v. Board of Education, 347 U.S. 483. [Periodical] Retrieved from the Library of Congress, https://www.loc.gov/item/usrep347483/.

Washington, H. A. (2019). A terrible thing to waste: Environmental racism and its assault on the American mind. Hachette UK.

Williams, R. L. (1997). The ebonics controversy. Journal of Black Psychology, 23(3), 208-214. https://doi.org/10.1177/00957984970233002 


\section{CHILD DEVELOPMENT AND THE PURSUIT OF EQUALITY}

Zucker, J. K., \& Patterson, M. M. (2018). Racial Socialization Practices Among White American

Parents: Relations to Racial Attitudes, Racial Identity, and School Diversity. Journal of

Family Issues, 39, 3903-3930. https://doi.org/10.1177/0192513X18800766 